University of Nebraska - Lincoln

DigitalCommons@University of Nebraska - Lincoln

1974

\title{
DIURNAL RHYTHM IN SERUM TESTOSTERONE LEVELS AND THYMIDINE UPTAKE BY TESTES IN THE DOMESTIC FOWL
}

B. D. Schanbacher

Johns Hopkins University

W. R. Gomes

Ohio State University

N. L. VanDemark

Ohio State University

Follow this and additional works at: https://digitalcommons.unl.edu/usdaarsfacpub

Part of the Agricultural Science Commons

Schanbacher, B. D.; Gomes, W. R.; and VanDemark, N. L., "DIURNAL RHYTHM IN SERUM TESTOSTERONE LEVELS AND THYMIDINE UPTAKE BY TESTES IN THE DOMESTIC FOWL" (1974). Publications from USDAARS / UNL Faculty. 751.

https://digitalcommons.unl.edu/usdaarsfacpub/751

This Article is brought to you for free and open access by the U.S. Department of Agriculture: Agricultural Research Service, Lincoln, Nebraska at DigitalCommons@University of Nebraska - Lincoln. It has been accepted for inclusion in Publications from USDA-ARS / UNL Faculty by an authorized administrator of DigitalCommons@University of Nebraska - Lincoln. 


\title{
DIURNAL RHYTHM IN SERUM TESTOSTERONE LEVELS AND THYMIDINE UPTAKE BY TESTES IN THE DOMESTIC FOWL
}

\author{
B. D. Schanbacher ${ }^{1}$, W. R. Gomes and N. L. VanDemark \\ The Ohio State University and Ohio Agricultural Research and Development \\ Center, Columbus ${ }^{2}, 43210$
}

\begin{abstract}
Summary
Serum testosterone levels were measured by radioimmunoassay at 3 -hr. intervals in a total of 80 mature Dwarf Leghorn cocks, and incorporation of thymidine- ${ }^{3} \mathrm{H}$ in testes was measured by radioautography in an additional 24 birds. Serum testosterone was higher at night $(\mathrm{P}<0.02)$, averaging $7.14 \pm 0.55 \mathrm{ng} / \mathrm{ml}$ during light hours $(0900-1800 \mathrm{hr}$.), and $9.42 \pm 0.73$ $\mathrm{ng} / \mathrm{ml}(\mathrm{P}<0.02)$ during darkness $(2100-0600$ hr.). In a second experiment to determine the rate of incorporation of thymidine into testes, birds were inadvertently subject to continuous artificial light during the 24hr. study period; uptake of thymidine- ${ }^{3} \mathrm{H}$ did not differ between day and nighttime periods, averaging $174 \pm 5$ and $177 \pm 4$ tritium-labeled cells per $\mathrm{mm}^{2}$, respectively. These data suggest that, during the Ohio spring season, testosterone production is favored at night. Spermatogenic DNA production may not vary diurnally, but the unusual lighting scheme involved may have altered the normal picture.
\end{abstract}

\section{Introduction}

Although much of the reproductive seasonality of wild birds has been lost in domestic fowl, dramatic effects of light and temperature are evident in the domesticated species. Many of these effects are exhibited in the expression of diurnal rhythms in such factors as blood glucose (Twiest and Smith, 1970), body and testicular temperature (Langford and Howarth,

\footnotetext{
${ }^{1}$ Present address: Department of Population Dynamics, Johns Hopkins University, Baltimore, Md.

${ }^{2}$ Contribution from the Animal Reproduction Teaching and Research Center and the Department of Dairy Science. Joumal Article No. 13673, Ohio Agricultural Research and Development Center.
}

1972), ejaculate volume (Lake and Wood-Gush, 1956), gonadotropin levels (Murton, Bagshowe and Lofts, 1969) and spermatogenic activity (Riley, 1940). Although some workers have observed that spermatogenic activity of fowl testes increases at night (Langford and Howarth, 1972), conflicting data exist (McCartney, 1942). Data on diurnal changes in testosterone production are not available.

This study was undertaken to determine whether serum testosterone levels in domestic fowl fluctuate according to a diurnal cycle, and to reevaluate the diurnal activity of the seminiferous epithelium by measuring the incorporation of thymidine- ${ }^{3} \mathrm{H}$ into testes.

\section{Experimental Procedures}

Serum Testosterone. For the testosterone study, 80 mature Dwarf Leghom (dw dw; Hutt, 1959) cocks were randomly assigned for collection of blood at one of eight time periods throughout the day, including both light $(0900$, 1200,1500 and $1800 \mathrm{hr}$.) and dark (2100, 2400, 0300 and $0600 \mathrm{hr}$.) periods. All birds were provided feed and water ad libitum and maintained at an ambient temperature of at least $20 \mathrm{C}$. Photoperiod length was $14 \mathrm{hr}$. with lights turned on at 0600 hour.

Blood was collected from the brachial vein and serum was removed by centrifugation at 4 C. $(3000 \times g)$. Serum testosterone was estimated using a radioimmunoassay employing antibody against testosterone-3-(0-carboxymethyl) oxime bovine serum albumin. The assay procedures and characteristics of the antiserum have been reported (Gomes et al., 1973).

Thymidine Incorporation. In a second experiment, 24 additional cocks under similar 
conditions were fasted for $12 \mathrm{hr}$. and used to evaluate spermatogenic activity at the eight different time periods. A single intratesticular injection of $50 \mu \mathrm{Ci}$ of thymidine ${ }^{3} \mathrm{H}$ (Go, Vernon and Fritz, 1972) was given following surgical exposure of the right testis. This procedure was accomplished by making an incision between the last two ribs and inserting a spreader so that the testis could be readily visualized. The lights were inadvertently left on during the night of the thymidine incorporation experiment. However, it was noted that birds tended to follow their normal circadian rhythm, i.e., they were quiescent and apparently asleep during the hours when lights were normally off.

Two hours after tritiated-thymidine injection, cocks were sacrificed and testes were taken immediately to be prepared for radioautography. After slides had been exposed to NTB emulsion (Baserga, 1967) for 2 weeks, the number of cells which had incorporated the DNA precursor were counted and expressed on a per unit area basis.

Statistical comparisons of means in both segments of this study were accomplished using the t-test.

\section{Results and Discussion}

Serum Testosterone. Testosterone concentrations in the serum averaged $7.39 \pm 1.43,7.03$ $\pm 1.26,7.17 \pm 0.93$, and $7.00 \pm 0.57 \mathrm{ng} / \mathrm{ml}$ for birds collected at $0900,1200,1500$ and 1800 hr., respectively (figure 1). After darkness, values were $8.59 \pm 1.52,8.94 \pm 1.15,8.82 \pm$ 1.43 and $11.29 \pm 1.75 \mathrm{ng} / \mathrm{ml}$ at 2100,2400 , 0300 and $0600 \mathrm{hr}$., respectively. The 40 birds collected during darkness (2100-0600 hr.) averaged $9.42 \pm 0.35 \mathrm{ng}$ testosterone $/ \mathrm{ml}$ serum, compared to $7.14 \pm 0.55 \mathrm{ng} / \mathrm{ml}(\mathrm{P}<0.02)$ for 40 birds collected during the light period (0900-1800 hr.; figure 1), indicating that testosterone fluctuates diurnally.

The serum testosterone values found for this study are somewhat higher than those reported by other workers using a different strain of bird and different assay methods (Furr and Thomas, 1970; Schrocksnadel, Bator and Frick, 1971); as well, these workers presumably collected all their samples during light periods.

Several reports have demonstrated that plasma testosterone also shows significant diurnal variation in mammalian species. In man, peak values were found at $0600 \mathrm{hr}$. (Resko and Eik-Nes, 1966; Faiman and Winter, 1971; Rose et al., 1972) and minimum levels at 1800 (Rose

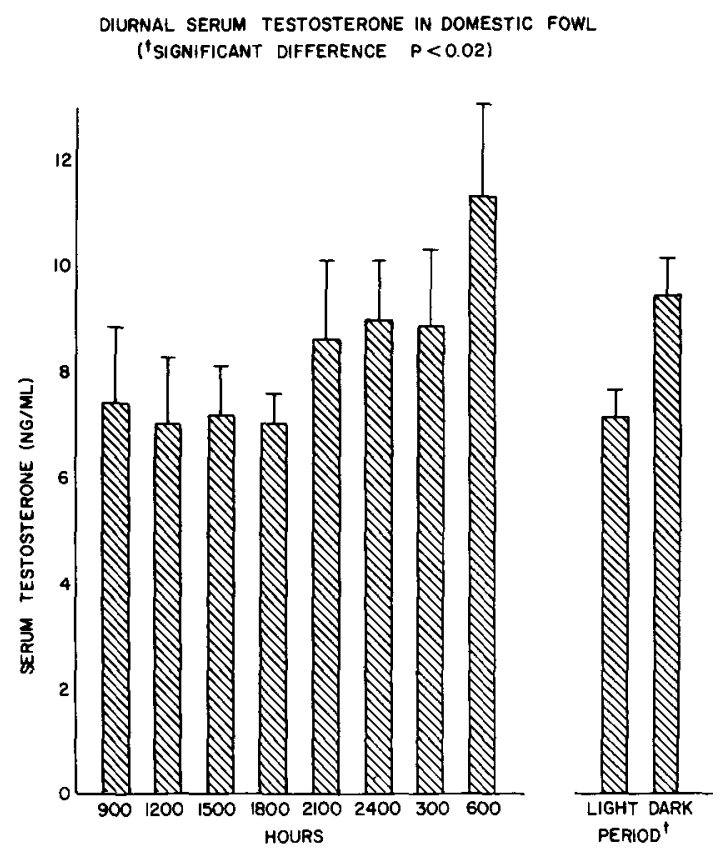

Figure 1. Serum testosterone levels at 3 -hr. intervals in Dwarf Leghorn cocks. Each bar represents mean+SE for 10 birds. Light period is the average of 40 birds bled at 0900-1800 hr. and dark period represents bleedings at $2100-0600 \mathrm{hr}$. inclusive.

et al., 1972). Because man is less dependent, reproductively, on light than the bird, the similarity of testosterone rhythms in the two species raises the question of factors primarily influencing output of the hormone: i.e., is the nighttime increase a response to darkness, temperature, inactivity, or other factors? In a nocturnal species, the rat, day time testosterone levels were $50 \%$ higher than those collected at night (Mock and Frankel, 1973).

Thymidine Incorporation. Figure 2 illustrates the typical pattern of thymidine $-{ }^{3} \mathrm{H}$ incorporation into spermatogonia and preleptotene spermatocytes of the fowl testis. By quantifying the number of label-containing cells in a $10 \mathrm{~mm}^{2}$ area of 100 random fields, comparisons were made of thymidine incorporation into testicular DNA at different time periods. As shown in figure 3 , no relationship between normal day: night patterns and thymidine ${ }^{3} \mathrm{H}$ incorporation was found: testes injected during the hours of normal darkness contained $177 \pm 4$ ${ }^{3}$ H-labeled cells $/ \mathrm{mm}^{2}$, compared to $174 \pm 5$ for testes from cocks treated during light hours. These data are in contrast to those of Langford 


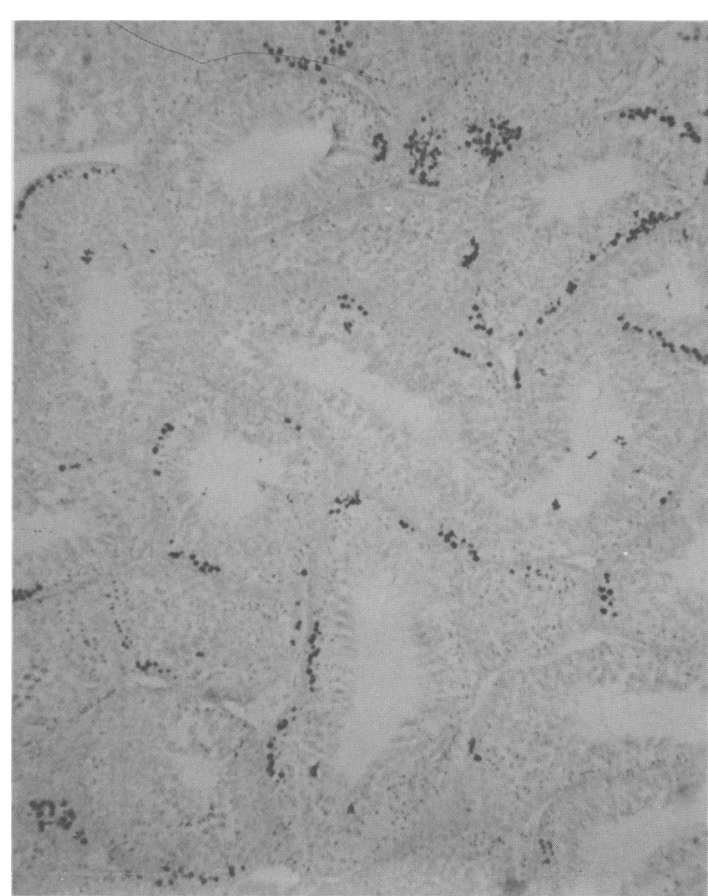

Figure 2. Radioautograph showing ${ }^{3} \mathrm{H}$-thymidine incorporation into fowl testis (X120). and Howarth (1972) who reported the uptake of tritiated thymidine to be maximal between 1200 and $0200 \mathrm{hr}$, a time when testicular temperature was lowest, while uptake was minimal between 0700 and 0900 hours. Although birds were apparently asleep at night during the thymidine study reported here, the possibility exists that the continuous lighting during thymidine administration abolished any diurnal rhythm in incorporation of the compound by testes. If this is the case, the immediate effects of light on spermatogenic activity apparently override long-standing rhythms. MaCartney (1942), evaluating spermatogenic activity in White Leghorns, observed the highest number of metaphase plates during the afternoon and at night (1000-0400), with no day:night differences apparent.

The data from the present study indicate that the Dwarf Leghorn cock exhibits a diurnal rhythm in testosterone production, but no day:night differences were found in tubular DNA production, under the unusual lighting conditions imposed on the thymidine-treated birds.
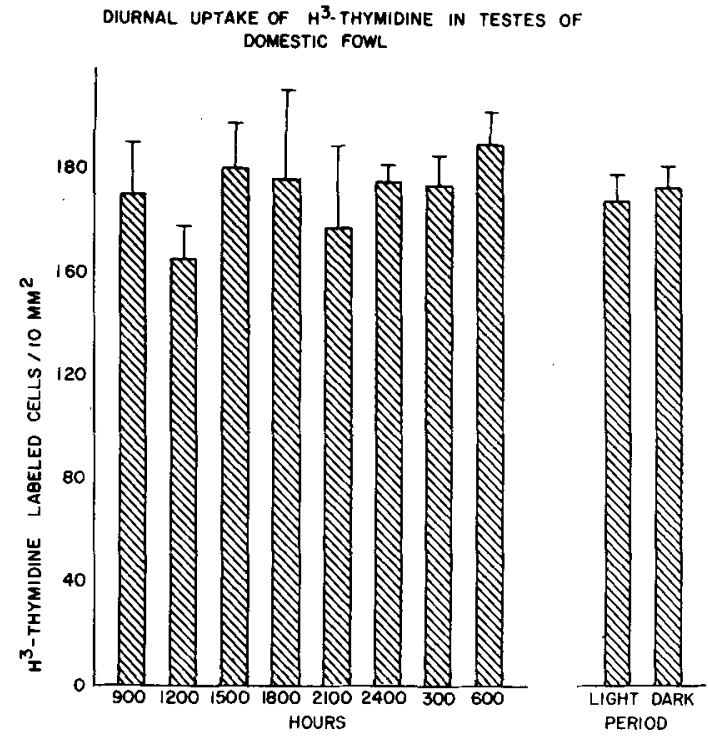

Figure 3. Incorporation of $\mathbf{H}$-thymidine into spermatogenic cells at 3-hr. intervals in Dwarf Leghorn cocks. Each bar represents mean+SE from three birds.

\section{Literature Cited}

Baserga, R. 1967. Autoradiographic methods. In H. Busch (Ed.) Methods in Cancer Research, Vol. I. Academic Press, New York.

Faiman, C. and J.S.D. Winter. 1971. Diurnal cycles in plasma FSH, testosterone and cortisol in man. J. Clin. Endocrinol. Metab. 33:186.

Furr, B.J.A. and B.S. Thomas. 1970. Estimation of testosterone in plasma of the domestic fowl. J. Endocrinol. 48:xlii (Abstr.).

Go, V.L.W., R. G. Vernon and I.B. Fritz. 1971. Studies on spermatogenesis in rats. I. Application of the sedimentation velocity technique to an investigation of spermatogenesis. Can. J. Biochem. 49:753.

Gomes, W. R., R. W. Hall, S.K. Jain and L.R. Boots. 1973. Serum gonadotropin and testosterone levels during loss and recovery of spermatogenesis. Endocrinol. 93:800.

Hutt, F.B. 1959. Sex-linked dwarfism in the fowl. J. Hered. 50:209.

Lake, P.E., D.G.M. Wood-Gush. 1956. Diurnal rhy thm in semen yields and mating behaviour in the domestic cock. Nature 178:853.

Langford, B.B. and B. Howarth, Jr. 1972. Diurnal rhythm of testicular temperature and spermatogenic activity in the domestic fowl. Poul. Sci. 51:1828 (Abstr.).

MaCartney, E.L. 1942. Diurnal rhythm of mitotic activity in the seminiferous tubules of the domestic fowl. Poul. Sci. 21:130.

Mock, E.J. and A.I. Frankel. 1973. Diurnal variation of plasma testosterone in male rats. Proc. 6th Ann. Meet., Soc. Study Reprod., Athens, Ga.

Murton, R.K.. K.D. Bagshawe and B. Lofts. 1969. The 
circadian basis of specific gonadotrophin release in relation to avian spermatogenesis. J. Endocrinol. 45:311.

Resko, J.A. and K. B. Eik-Nes. 1966. Diurnal testosterone levels in peripheral plasma of human male subjects. J. Clin. Endocrinol. Metab. 26:573.

Riley, G.M. 1940. Diurnal variations in spermatogenic activity in the domestic fowl. Poul. Sci. 19:360 (Abstr.).
Rose, R.M., L. Kreuz, J. Holaday, K. Sulak and C. Johnson. 1972. Diurnal variation of plasma testosterone and cortisol. J. Endocrinol. 54:177.

Schrocksnadel, H., A. Bator and J. Frick. 1971 Plasma testosterone levels in cocks and hens. Steroids 18:359.

Twiest, G. and C.J. Smith. 1970. Circadian rhy thm in blood glucose level of chickens. Comp. Biochem. Physiol. 32:371. 